\title{
The creative accounting in determining the bankruptcy of Business Corporation
}

\author{
Erika Kovalová ${ }^{1, *}$ and Katarína Frajtová Michalíková ${ }^{2}$ \\ ${ }^{1}$ University of Zilina, Faculty of Operation and Economics of Transport and Communication, \\ Department of Economics, Univerzitna 8215/1, 01026 Zilina, Slovak Republic \\ ${ }^{2}$ University of Zilina, Faculty of Operation and Economics of Transport and Communication, \\ Department of Economics, Univerzitna 8215/1, 01026 Zilina, Slovak Republic
}

\begin{abstract}
If there is a period of unfavourable to critical economic development Business Corporation, there is no doubt about the significance of determining the actual factual moment of bankruptcy of the business corporation. In such a situation, it is crucial for further development approach of the statutory body of Business Corporation in terms of truly evaluation and timely search for a constructive solution. There are different methods of creative accounting to delaying the impending corporation bankruptcy. This paper describes the individual ways in which the creative accounting can favour the business corporation, e.g. increase the reported earnings or reduce the reported loss, manipulate with indicators used in financial analysis, conceal financial risk or strengthen the company's access to finance. The reason for using these practices by the company management can be just a simple delay in solving the situation, trying to keep the company position as long as possible or the reasons are more complex and sophisticated. There are many model to predict the adjusting financial statements. We described and applied two of them, the CFEBT model and BENEISH M-score model.
\end{abstract}

\section{Introduction}

Accounting should give a true and fair view of the financial and profit situation of the company. For this purpose, its outputs are in the form of financial statements, which are relied on by external and internal users, and according these statements are the economic decisions made. Trying to present the entity "in the better light" leads the management of many businesses to artificial improvement of results. Another reason for manipulating the statements is to attract more investors as well as an effort to reduce the tax base by undervaluing revenue or overestimating costs. [9]

The most common definition the appears in the literature refers to creative accounting as a process of manipulating accounting data to transform financial statements into that they should take, in the form their creators would like. [2,15] Another definition says that creative accounting consists of accounting practices that follow required laws and

\footnotetext{
*Corresponding author: erika.kovalova@fpedas.uniza.sk
} 
regulations, but deviate from what those standards intend to accomplish. [4] Practices of the creative accounting is therefore dishonest, because it is a deliberate misrepresentation of information. [2, 5] Chartered Institute of Management Accounting [5] define the creative accounting as a form of accounting which by complying with all regulations gives a biased (generally favourable) view of business performance. However, there are approaches that take a broader view of creative accounting $[2,15]$. Creative accounting is all the steps used to play with financial statements including aggressive selection and application of accounting principles, whether within of across the board of accepted accounting principles and fraudulent financial reporting.

\section{Methodology and data}

If there was a period of unfavourable to critical corporate economic development, there is no doubt determining any actual moment of corporate bankruptcy, but it is clear that exist very effectively methods and procedures for determining this moment. In such a situation, it is crucial for further development the approach of corporate statutory body in terms of truly evaluation and timely search for a constructive solution. At present, there are generally popular and applied various endeavours to artificially adjust the image of accounting to the form required for a certain purpose.

Creative accounting can benefit the business corporation by the following ways, may (i) increase or reduce the reported profit, (ii) manipulate with indicators used in financial analysis, (iii) conceal the financial risk or circumvent the risks associated with loans, (iv) help to avoid shareholder control, (v) strengthen the position of the company management or (vi) strengthen the corporate access to finance that would not be obtain in other ways. [1, 5]

On the other hand, the consequences of such practices may be particularly disadvantageous, especially in the form of distrust not only of potential creditors and investors, but also of business partners, eventually employees and the whole public. [6]

\subsection{Techniques of purpose manipulation}

The techniques of adjusting financial statements show varying degrees of difficulty, some cane be used by less savvy people to enhance the image of society to the desired form, (i) Windows dressing, other are more advanced and more difficult to recognize (ii) Offbalance sheet financing.

(i) Window dressing - according to the ICAEW [6] is Window dressing defined as keeping of accounting transactions in such a way that financial statements give a misleading or unrepresentative picture of the corporate financial situation.

The main techniques of Window dressing include:

- breach of the precautionary principle in accounting,

- distortion of revenue recognition that does not meet their definition,

- replacement the assets modernization for repair and vice versa,

- deliberate reporting of short-term assets and debt between long- term and vice versa,

- distortion of the valuation of assets in balance sheet at the time of acquisition,

- deprecation method - wrong estimation of assets useful life.

(ii) Off- balance sheet financing - according to ICAEW [6] is Off-balance sheet defined as financing or refinancing business activities that by the legal requirements of existing accounting principles need not appear in corporate balance sheet, e.g. 
Off-balance sheet financing is a method of financing where the assets and liabilities are not relevant in the corporate balance sheet, but appear in the balance sheet of other companies.

The main techniques of Off-balance sheet include:

- misstatement of the leasing, replacement of a finance leasing for an operating leasing,

- guaranteed loans considered as gain

- loans classified as equity,

- $\quad$ non-recognition of obligations arising from the non-payment of claim. [5,7]

Ultimately, manipulation with accounting makes impossible to truthful and objective assessing the status and situation of a business corporation after violating a true and truthful image of accounting and challenging the transparency and predicative ability of financial statements. $[1,9,11]$

\subsection{CFEBT model}

There is no doubt about the importance and preference of the issue of verifying truth of an information statement. Reliable verification methods in conjunction with their precise legislative anchoring would certainly be a significant contribution in many of the actual discovery processes of corporate insolvency proceedings. Development and elaboration of such methods is constantly in progress, e.g. the creation of a CFEBT model. [3,7]

The CFEBT model was created with a focus on companies operating in the Czech Republic. Given the relatedness of the Slovak and Czech market, the model will be used and interpreted on the Slovak company. [10]

The main definition is based on this formula: [8]

$$
C F E B T=\sum_{\mathrm{t}=1}^{5}\left(\frac{\Delta C F_{\mathrm{t}}-E B T_{\mathrm{t}}}{E B T_{\mathrm{t}}}\right)
$$

If CFEBT > materiality (usually 5-10\%), there is an increased risk of manipulating the true and fair view of reality. In this case, it is necessary to analyse the significant changes between Cash flow and the economic result, this deviation may be caused by large-scale corporate investment. $[3,8]$

\subsection{BENEISH M-score model}

BENEISH M-score model is a mathematical model containing eight variables that can be used to identify possible data manipulation based on the financial statements. The main definition relationship is based on the equation: [6]

$$
\begin{aligned}
\text { M Score }=-4,84 & +0,92 \mathrm{DSRI}+0,528 \mathrm{GMI}+0,404 \mathrm{AQI}+0,892 \mathrm{SGI}+0,115 \mathrm{DEPI} \\
& -0,172 \mathrm{SGAI}+4,679 \mathrm{TATA}-0,327 \mathrm{LVGI}
\end{aligned}
$$

If M-Score is less than $-2,22$, the company is unlikely to be a manipulator, and vice versa, if M-Score is greater than $-2,22$, the company is likely to be a manipulator. The variables of Beneish $\mathrm{M}$ - score model are explained in the Table 1. 
Table 1. BENEISH M-score model

\begin{tabular}{|c|c|}
\hline & Characteristics \\
\hline $\begin{array}{c}\text { DSRI } \\
\text { Day Sales in } \\
\text { Receivables Index }\end{array}$ & DSRI $=($ Net Receivablest $/$ Sales $t) /($ Net Receivablest $-1 /$ Salest -1$)$ \\
\hline $\begin{array}{l}\text { GMI } \\
\text { Gross Margin Index }\end{array}$ & $\mathrm{GMI}=\left[\left(\right.\right.$ Salest-1 $\left._{-} \mathrm{COGS}_{\mathrm{t}-1)}\right) /$ Salest-1] $] /\left[\left(\right.\right.$ SaleSt $\left._{\mathrm{t}}-\mathrm{COGS}_{\mathrm{t}}\right) /$ Salest $]$ \\
\hline $\begin{array}{c}\text { AQI } \\
\text { Asset Quality Index }\end{array}$ & $\begin{array}{l}\mathrm{AQI}=\left[1-\left(\text { Current Assetst }+ \text { PP\&E } \mathrm{E}_{\mathrm{t}}+\text { Securities }_{\mathrm{t}}\right) / \text { Total Assetst }\right] /[1- \\
\quad((\text { Current Assetst }-1+\text { PP\&Et-1 }+ \text { Securitiest } 1) / \text { Total Assetst }-1)]\end{array}$ \\
\hline $\begin{array}{c}\text { SGI } \\
\text { Sales Growth Index }\end{array}$ & SGI $=$ Sales $_{t} /$ Salest -1 \\
\hline $\begin{array}{c}\text { DEPI } \\
\text { Depreciation Index }\end{array}$ & 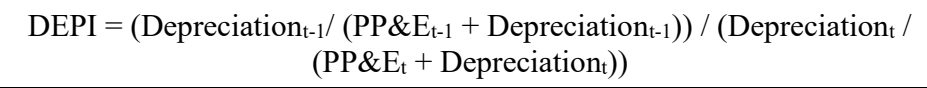 \\
\hline $\begin{array}{c}\text { SGAI } \\
\text { Sales General and } \\
\text { Administrative } \\
\text { Expenses Index }\end{array}$ & $\mathrm{SGAI}=\left(\mathrm{SG} \& A\right.$ Expense $_{\mathrm{t}} /$ Sales $\left._{\mathrm{t}}\right) /\left(\mathrm{SG} \& A\right.$ Expense $\mathrm{t}_{-1} /$ Salest -1$)$ \\
\hline $\begin{array}{c}\text { TATA } \\
\text { Total Accruals to } \\
\text { Total Assets } \\
\end{array}$ & $\begin{array}{c}\mathrm{TATA}=(\text { Income from Continuing Operations } \mathrm{t}-\text { Cash Flows from } \\
\text { Operationst }) / \text { Total Assets } \mathrm{t}\end{array}$ \\
\hline $\begin{array}{c}\text { LVGI } \\
\text { Leverage Index }\end{array}$ & $\begin{array}{c}\text { LVGI }=\left[\left(\text { Current Liabilities } t+\text { Total Long Term Debt } t_{t}\right) / \text { Total Assetst }\right] / \\
\quad\left[\left(\text { Current Liabilitiest }-1+\text { Total Long Term Debt } t_{-1}\right) / \text { Total Assets } t_{-1}\right]\end{array}$ \\
\hline
\end{tabular}

Source: [12]

\section{Results}

In this part of paper, we have compared two models, e.g. CFEBT model and BENEISH Mscore model, which were explained above, on two companies. Both companies (Company A and Company B) are medium-size, and both provides services.

\subsection{CFEBT model}

CFEBT model has, according to us opinion, very interesting predicative function. Many indicators of financial analysis depend on the value of reported profits. Therefore, the company motivation is to show fictitious sales, and the emphasis should be on cash flow. The implementation of CFEBT model is based on publicly available corporate statements. 
Table 2. Model CFEBT of Company A

\begin{tabular}{|c|c|c|c|c|c|c|}
\hline $\begin{array}{c}\text { Company } \\
\text { A }\end{array}$ & $\mathbf{2 0 1 8}$ & $\mathbf{2 0 1 7}$ & $\mathbf{2 0 1 6}$ & $\mathbf{2 0 1 5}$ & $\mathbf{2 0 1 4}$ & $\mathbf{2 0 1 4 - 2 0 1 8}$ \\
\hline $\mathrm{CF}_{\mathrm{t}-1}$ & 798927 & 856212 & 901456 & 890477 & 1021998 & 3447072 \\
\hline $\mathrm{CF}_{\mathrm{t}}$ & 702654 & 799854 & 930228 & 978520 & 912356 & 4323612 \\
\hline$\Delta \mathrm{CF}$ & -96273 & -56358 & 28772 & 88043 & -109642 & -145458 \\
\hline $\mathrm{EBT}$ & -15248 & 625221 & 425362 & 102809 & 302556 & 1440700 \\
\hline CFEBT & \multicolumn{5}{|l|}{} & $\mathbf{- 1 1 0 \%}$ \\
\hline
\end{tabular}

Source: own processing

Table 3. Model CFEBT of Company B

\begin{tabular}{|c|c|c|c|c|c|c|}
\hline $\begin{array}{c}\text { Company } \\
\text { B }\end{array}$ & $\mathbf{2 0 1 8}$ & $\mathbf{2 0 1 7}$ & $\mathbf{2 0 1 6}$ & $\mathbf{2 0 1 5}$ & $\mathbf{2 0 1 4}$ & $\mathbf{2 0 1 4 - 2 0 1 8}$ \\
\hline $\mathrm{CF}_{\mathrm{t}-1}$ & 415225 & 399852 & 98754 & 220159 & 256998 & 1390988 \\
\hline $\mathrm{CF}_{\mathrm{t}}$ & 95825 & 425889 & 395225 & 110556 & 218112 & 1245607 \\
\hline$\Delta \mathrm{CF}$ & -319400 & 26037 & 296471 & -109603 & -38886 & -145381 \\
\hline $\mathrm{EBT}$ & -98662 & 69115 & -255127 & -22705 & 31991 & -275388 \\
\hline CFEBT & \multicolumn{5}{|l|}{} & \\
\hline
\end{tabular}

Source: own processing

By applying the CFEBT model, we found a sharp discrepancy between the reported income and the reported revenue in the Company A. In the deeper analysis, however, this difference was mainly due to the opening of new company operation in the years 2014 and 2017. This company recorded very high capital expenditures, which were not reflected in the economic results, only in the negative $\mathrm{CF}$ in the form of investment activities.

In the Company B, there is the difference $47,21 \%$, which was caused by an increase in short-term liabilities. In 2014, the Company B assets were covered by short-term external resources of more than $80 \%$.

\subsection{BENEISH M-score model}

BENEISH M-score model can be used to determine corporate financial fraud. The better the prospects of the company, the better it can be used to detect financial fraud. On the other hand, depreciation, cost of sales, and discretionary accrual on accounting policy may reduce the ability to detect financial fraud. Indication of recognition on increasing revenue and profit, suspension on cost of the asset, as well as the amount of debt to creditors cannot be used for detecting financial fraud. [9]

In the next tables, there is show the result of the BENEISH M-score model, used on the two companies. 
Table 4. BENEISH M-score model of Company A

\begin{tabular}{|c|c|c|c|c|}
\hline Company A & $\mathbf{2 0 1 8}$ & $\mathbf{2 0 1 7}$ & $\mathbf{2 0 1 6}$ & $\mathbf{2 0 1 5}$ \\
\hline DSRI & 2,6331 & 1,7506 & 0,8330 & 0,4022 \\
\hline GMI & 0 & 0 & 0 & 0 \\
\hline AQI & 0,6320 & 0,5376 & 0,3874 & 6,9161 \\
\hline SGI & 1,0255 & 0,9810 & 1,5949 & 1,3027 \\
\hline DEPI & 0,9066 & 0,9564 & 1,2028 & 1,1938 \\
\hline SGAI & 1,1530 & 0,0778 & 0,0014 & 1,1408 \\
\hline TATA & 6,9960 & 6,7354 & 7,2659 & 4,2234 \\
\hline LVGI & 0,9951 & 0,9671 & 0,7666 & 0,9762 \\
\hline BENEISH M-score & $\mathbf{3 1 , 0 7}$ & $\mathbf{2 9 , 1 6}$ & $\mathbf{3 1 , 3 9}$ & $\mathbf{1 8 , 5 7}$ \\
\hline
\end{tabular}

Source: own processing

Table 5. BENEISH M-score model of Company B

\begin{tabular}{|c|c|c|c|c|}
\hline Company B & $\mathbf{2 0 1 8}$ & $\mathbf{2 0 1 7}$ & $\mathbf{2 0 1 6}$ & $\mathbf{2 0 1 5}$ \\
\hline DSRI & 1,3430 & 1,1890 & 1,1240 & 1,1587 \\
\hline GMI & 0 & 0 & 0 & 0 \\
\hline AQI & 1,9333 & 1,1246 & 1,0086 & 1,8057 \\
\hline SGI & 1,0740 & 1,0786 & 0,9136 & 1,0017 \\
\hline DEPI & 1,0882 & 0,2779 & 1,0888 & 2,2893 \\
\hline SGAI & 0,6113 & 1,5520 & 1,1251 & 2,4710 \\
\hline TATA & 2,1964 & 1,8568 & 1,7443 & 2,8505 \\
\hline LVGI & 0 & 0 & 0 & 0 \\
\hline BENEISH M-score & $\mathbf{8 , 4 3}$ & $\mathbf{6 , 1 2}$ & $\mathbf{5 , 5 1}$ & $\mathbf{1 1 , 0 2}$ \\
\hline
\end{tabular}

Source: own processing

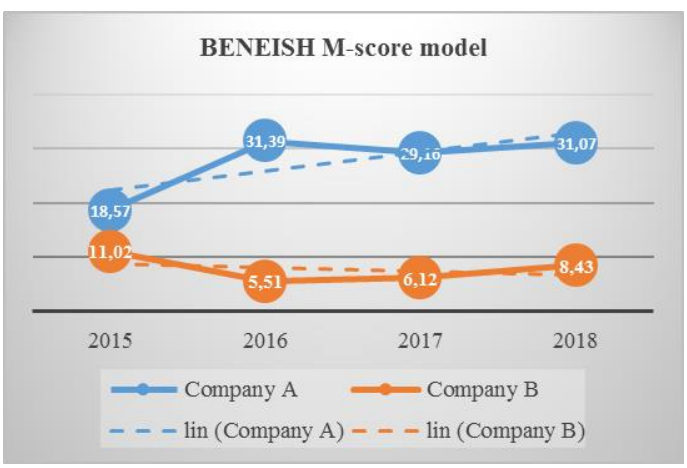

Fig. 1. BENEISH M-score model

Source: own processing

In the figure 1, there is shown that Company A has a significant difference in comparison with the threshold of BENEISH M-score model and also in comparison with the second analysed company, Company B. The figure also shows that the values of the BENEISH model tend to deteriorate over time in the Company A.

Company A compared to Company B, shows the worst result in the possible manipulation of the financial statements of the last five years. 


\section{Conclusion}

Economic crime is constantly evolving, and there was also a sharp increase in Slovak Republic in recent years. It is well know that various distortions in economic results have led to the bankruptcy of several huge companies. Such fraudulent action may therefore have far-reaching consequences not only for the company's owners but also for its own employees and the wider environment.

The main objective of this paper was to analyse trends in fraudulent practices in corporate accounting and to evaluate selected instruments of prevention and detection of fraudulent behaviour to two companies Two of the methods of detecting fraud are CFEBT and BENEISH model. In our opinion, the least known CFEBT model, which puts the corporate reported profits with its real cash flows, has a very interesting predicative ability. The means of detecting fraudulent activities clearly include the well-implemented internal control system of the company. First of all, companies should think about the right prevention techniques that can prevent fraud before it occurs.

The paper is an output of the science project VEGA 1/0210/19 Research of innovative attributes of quantitative and qualitative fundaments of the opportunistic earnings modelling.

\section{References}

1. Breda, N., Horák, J., Kovacova, M., Valaskova, K. The Future of Work: Disruptive Business Practices, Technology-Driven Economic Growth, and Computer-Induced Job Displacement. Journal of Self-Governance and Management Economics 6(4), 19-24. (2018)

2. Č́rtková, L. Podvody, zpronevěry, machinacce: (možnosti prevence, odhalování a ochrany pred podvodným jednáním). Vyd. 1. Praha: Armex (2005)

3. Drábková, Z. Models of detection manupulated financial statements a spart of the intermal control system of the entity. ACRN Oxford Jorunal of Finance and Risk Perspectives. 51, 230-238. (2016)

4. Evans, O. Improved financial performance without improved operational efficiency: The case of Nigerian firms, Forum Scientiae Oeconomia, 6(3), 25-39. (2018)

5. Greblikaite, J., Sroka, W., Grants, J. Development of Social Entrepreneurship in European Union: Policy and Situation of Lithuania and Poland, Transformations in Business \& Economics, 14(2B), 376-369 (2015)

6. Herawati, N. Application of Beneish M-score models and data mining to detect financial fraud. In: Procedia- Social and Behavioral Sciences. 211, 924-930 (2015)

7. Kováčová, M., Rowland Z. Kreatívne účtovníctvo ako latentný nástroj earnings managemntu, In: Podniková ekonomika a manažment. 3, 36-42 (2018)

8. Milesi-Ferretti, G.M. Good, bad or ugly? On the effects of fiscal rules with creative accounting. Journal of Public Economics. 88, 377-394 (2004)

9. Petrucelli, J. R. Detecting Fraud in Oranizations: Techniques, Tools, and Resources. Wiley (2013)

10. Shah, S.Z.A., Butt, S., A., Tagir Y., B. (2011). Use or Abuse of Creative Accounting Techniques. International Journal of Trade, Economics and Finance. 2, 531-536 (2011)

11. Siekelova, A, Kollar, B., Weissova, I. Impact of credit risk management. Procedia Economics and Finance, 26, 325-331. (2015) 
12. Tumpach, M. Beneishov model odhal'ovania bilančných podvodov. [online]. http://www.fhi.sk/files/katedry/ku/Forenzne/Beneishov-model.pdf (2015)

13. Valaskova, K., Kramarova, K., Kollar, B. Theoretical Aspects of a model of credit risk determination- Credit risk. Advances in Education Research, 81, 401-406. (2015)

14. Volkánová, Z. Podvody v účetnictví firem: jak se jim bránit. Praha: Linde (2014)

15. Weissova, I., Kollar, B., Siekelova, A. Rating as a useful tool for credit risk management. Procedia Economics and Finance, 26, 278-285. (2015) 